Section Editor

Mitchell S.V. Elkind, MD, MS

\section{Teaching NeuroImages: \\ Rosai-Dorfman disease presenting with progressive early-onset cerebellar ataxia}

Carolina Candeias da Silva, MD

José Luiz Pedroso, MD, $\mathrm{PhD}$

Fabiano Moulin de Moraes, MD

René Leandro M. Rivero, $\mathrm{MD}, \mathrm{PhD}$

Fabiano Mesquita Callegari, MD

Francisco Araujo, Jr, MD Fabio Fieni Toso, MD João Norberto Stávale, $\mathrm{MD}, \mathrm{PhD}$

Orlando Graziani Povoas Barsottini, MD, PhD

Correspondence to

Dr. Pedroso:

jlpedroso.neuro@gmail.com
Download teaching slides: www.neurology.org

Figure Imaging and histopathology

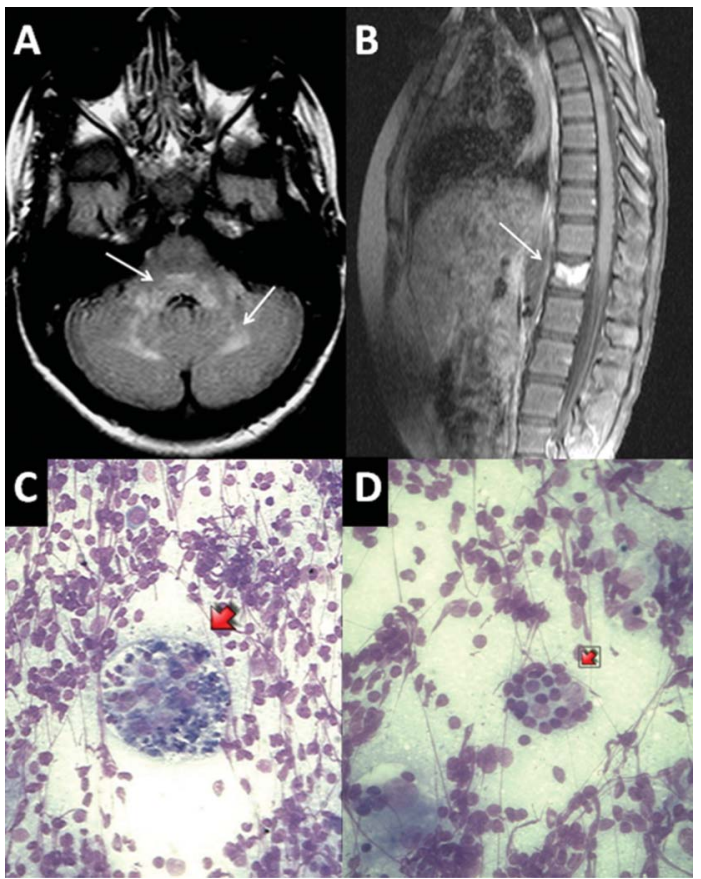

(A) Axial fluid-attenuated inversion recovery-weighted brain MRI shows cerebellar white matter (dentate nucleus), middle cerebellar peduncles, and dorsal pons involvement. (B) Spine MRI discloses a heterogeneous lesion with gadolinium enhancement on T12 vertebral body. (C, D) Cervical lymph node biopsy shows emperipolesis: histiocytes with abundant cytoplasm and engulfed viable lymphocytes, classically seen in Rosai-Dorfman disease.

A 13-year-old girl presented with a 3-year history of progressive gait abnormality. She recently had a selflimited cervical lymphadenopathy. Neurologic examination showed brisk tendon reflexes and moderate ataxia. Brain MRI disclosed hyperintense lesions in the cerebellum and pons (figure, A). Spine MRI showed a heterogeneous lesion in the T12 vertebra (figure, B). Histopathology of the cervical lymph node confirmed Rosai-Dorfman disease (RDD) by showing emperipolesis (figure, $\mathrm{C}$ and $\mathrm{D}$ ). The patient will be followed up in order to determine disease progression and therapy.

$\mathrm{RDD}$ is a rare autoimmune histiocytic proliferative disorder first recognized in $1969 .{ }^{1}$ The CNS is involved in 5\% of cases and generally mimics meningiomas. Bone erosion can be detected in the spine. ${ }^{2}$ Herein, we describe a rare CNS manifestation of RDD resembling a neurodegenerative ataxia.

\section{AUTHOR CONTRIBUTIONS}

Dr. da Silva: case description conception, neuroimaging conception, pathology conception, writing of the first draft (nothing to disclose). Dr. Pedroso: case description conception, case description organization, case description execution, neuroimaging organization, pathology organization, writing of the first draft, manuscript review and critique (nothing to disclose). Dr. Moraes: case description conception, neuroimaging conception, pathology conception, writing of the first draft. Dr. Rivero: neuroimaging conception, neuroimaging organization, manuscript review and critique. Dr. Callegari:

From the Department of Neurology, Ataxia Unit (C.C.d.S., J.L.P., F.M.d.M., F.F.T., O.G.P.B.), and Department of Pathology (F.M.C., F.A., J.N.S.), Universidade Federal de São Paulo; and Department of Radiology (R.L.M.R.), Universidade Federal de São Paulo and Delboni Auriemo, Diagnósticos da América, São Paulo, Brazil.

Go to Neurology.org for full disclosures. Funding information and disclosures deemed relevant by the authors, if any, are provided at the end of the article. 
pathology conception, pathology organization, manuscript review and critique. Dr. Araujo: pathology conception, pathology organization, manuscript review and critique. Dr. Toso: case description conception, neuroimaging conception, pathology conception, writing of the first draft. Dr. Stávale: pathology conception, pathology organization, manuscript review and critique. Dr. Barsottini: case description conception, case description organization, case description execution, writing of the first draft, manuscript review and critique.

\section{STUDY FUNDING}

No targeted funding reported.
DISCLOSURE

The authors report no disclosures relevant to the manuscript. Go to Neurology.org for full disclosures.

\section{REFERENCES}

1. Rosai J, Dorfman RF. Sinus histiocytosis with massive lymphadenopathy: a newly recognized benign clinicopathological entity. Arch Pathol 1969;87:63-70.

2. Purav P, Ganapathy K, Mallikarjuna VS, et al. Rosai-Dorfman disease of the central nervous system. J Clin Neurosci 2005;12: 656-659. 


\section{Neurology}

\section{Teaching NeuroImages: Rosai-Dorfman disease presenting with progressive early-onset cerebellar ataxia}

Carolina Candeias da Silva, José Luiz Pedroso, Fabiano Moulin de Moraes, et al. Neurology 2013;81;e27-e28

DOI 10.1212/WNL.0b013e31829d85d2

\section{This information is current as of July 29, 2013}

\section{Updated Information \& Services \\ Supplementary Material \\ References \\ Subspecialty Collections}

Permissions \& Licensing

Reprints including high resolution figures, can be found at: http://n.neurology.org/content/81/5/e27.full

Supplementary material can be found at: http://n.neurology.org/content/supp1/2013/07/28/81.5.e27.DC1

This article cites 2 articles, 0 of which you can access for free at: http://n.neurology.org/content/81/5/e27.full\#ref-list-1

This article, along with others on similar topics, appears in the following collection(s):

All Medical/Systemic disease

http://n.neurology.org/cgi/collection/all_medical_systemic_disease

Autoimmune diseases

http://n.neurology.org/cgi/collection/autoimmune_diseases

Gait disorders/ataxia

http://n.neurology.org/cgi/collection/gait_disorders_ataxia MRI

http://n.neurology.org/cgi/collection/mri

Information about reproducing this article in parts (figures,tables) or in its entirety can be found online at:

http://www.neurology.org/about/about_the_journal\#permissions

Information about ordering reprints can be found online: http://n.neurology.org/subscribers/advertise

Neurology ${ }^{\circledR}$ is the official journal of the American Academy of Neurology. Published continuously since 1951, it is now a weekly with 48 issues per year. Copyright (C) 2013 American Academy of Neurology. All rights reserved. Print ISSN: 0028-3878. Online ISSN: 1526-632X.

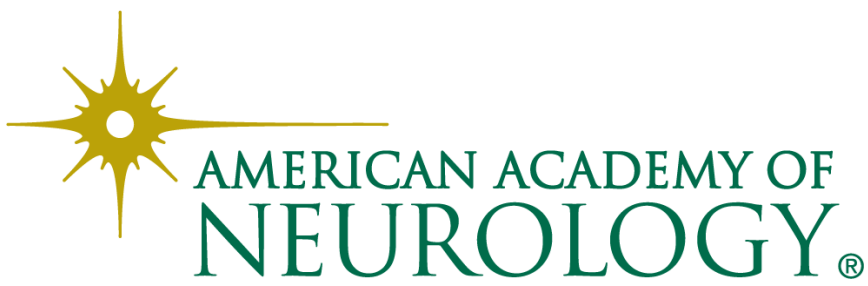

